\title{
Increased carnivory in Finnish red fox females - adaptation to a new competitor?
}

\author{
Suvi Viranta ${ }^{1} \&$ Kaarina Kauhala ${ }^{2}$ \\ 1) Department of Biomedicine/Anatomy, P.O. Box 63, FI-00014 University of Helsinki, Finland \\ (e-mail: suvi.viranta-kovanen@helsinki.fi) \\ 2) Finnish Game and Fisheries Research Institute, Itäinen Pitkäkatu 3 A, Fl-20520 Turku, Finland \\ (e-mail: kaarina.kauhala@rktl.fi)
}

Received 15 June 2010, revised version received 19 Nov. 2010, accepted 23 Nov. 2010

Viranta, S. \& Kauhala, K. 2011: Increased carnivory in Finnish red fox females - adaptation to a new competitor? - Ann. Zool. Fennici 48: 17-28.

Carnivore teeth, especially the carnassials, are subjects to selection in the presence of dietary competition. We compared several craniodental characters in the Finnish foxes before and after arrival of an invasive species, the raccoon dog. The female foxes displayed increased adaptation to carnivory, whereas we found no significant change in the male foxes after the arrival of the raccoon dog. We suggest that the presence of a new competitor may be driving the Finnish female foxes towards more carnivorous diet.

\section{Introduction}

Brown and Wilson (1956) launching the theory of character displacement suggested that where two similar species of animals are sympatric, their ecological, morphological or behavioral differences are accentuated. Competition for or partitioning of resources may not only result in interspecific divergence, but may be intraspecific occurring between sexes of the same species (Slatkin 1984, Shine 1989). Numerous studies in various taxa have exposed character displacement. In mammalian carnivores the dentition especially has confirmed the rule (Davies et al. 2007).

Several craniodental characters correlate with the diet in the carnivores. Skull shape and proportions reflect the bite, as well as the size and shape of the muscles of mastication (Van Valkenburgh 1990). Dietary adaptations are reflected by prominence of the appropriate teeth and their dimensions and/or number and shape of cusps.
The heterodont dentitions of carnivores have both slicing and grinding functions. Carnivores with a tendency toward more omnivorous diet typically have emphasis on the grinding molars, whereas more hypercarnivorous taxa have long blade-like lower carnassial trigonids and strong premolars good for meat slicing (Van Valkenburgh 1989). Although original works were done on larger carnivores, Friscia et al. (2007) showed similar trends in smaller carnivores including foxes.

Members of the family Canidae maintain the unique carnivore heterodonty. The carnassials are of special importance in their dietary adaptations (see Dayan et al. 1989). The trigonid length and breadth of the lower carnassial vary between species according to diet, but show little intraspecific variation (Meiri et al. 2005a). The canid canines, on the contrary, tend to have considerable intraspecific variation in size and shape and have weak correlation with dietary adaptations (Meiri et al. 2005a, 2005b). 
The red fox (Vulpes vulpes) is very adaptable, inhabiting in its Holarctic range many different environments from tundra and northern taiga to agricultural areas, deserts and even large cities (Baker \& Harris 2004, Holmala \& Kauhala 2009). Significant size variation between different fox populations has been found (Larivière \& Pasitschniak 1996). Regional differences have been correlated with sympatric species, climatic factors such as humidity, and latitude. Also morphological variation and variation in the degree of sexual dimorphism has been reported and correlated with differences in contemporary fauna or other environmental factors. Similar to canids in general, Dayan et al. (1992) showed that the morphology of fox carnassial and postcarnassial dentition is ecologically significant and related to food processing and hunting. Intense competition may increase sexual dimorphism in the fox carnassial pair and upper first molar: e.g. Szuma (2008a) found that species sympatric with other fox species have pronounced sexual dimorphism in these teeth.

The raccoon dog (Nyctereutes procyonoides) arrived in Finland from introductions made in the former Soviet Union (Lavrov 1971). The population spread from southeast, started to increase rapidly in southern and central Finland in the early 1970 s and is now established in the whole country except northern Lapland (Helle \& Kauhala 1991). Both the red fox and raccoon dog are adaptable, omnivorous and opportunistic canids (Larivière \& Pasitschniak-Arts 1996, Ward \& Wurster-Hill 1990, Sutor et al. 2010). Ecologies of the two now sympatric species in Finland have been studied to some detail (Kauhala 1993, Kauhala et al. 2006, Holmala \& Kauhala 2009). Results showed that foxes and raccoon dogs partly share their home ranges and food resources but the fox is more carnivorous of the two. There were no clear indications of competitive exclusion (Kauhala et al. 1998), although the fact that an experimental raccoon dog removal coincided with a temporary increase in the red fox population, indicates possible interaction (Kauhala 2004).

Here, we study dental and cranial morphometrics of a native canid species in Finland, the red fox, before and after the arrival of a potential canid competitor, the raccoon dog. Our study is unique studying short term temporal changes in a native species during an invasion of an alien species. For the southern Finland red foxes, we hypothesized three changes to have taken place as a result of the arrival of the raccoon dog:

1. Size increase. We predict that competition with a smaller and less carnivorous species will lead to a larger size of the red fox, when foxes shift to more carnivorous diet and select larger prey.

2. Morphological changes in the craniodental characters. We predict that the tendency toward hypercarnivory will lead to expression of more carnivorous traits in the dentition and will have the greatest effect on the carnassials and the cranial characters related to the muscles of mastication.

3. Increase in sexual dimorphism. We predict that increased competition will lead to prey partition between sexes and will result in increased dimorphism in the species.

We also studied the Lappish population. Our hypothesis predicted that the Lappish foxes were larger than those from southern Finland: body size tends to be positive correlated with latitude (Bergmann's rule, as cited in Mayr 1970).

\section{Material and methods}

\section{Material}

Skulls in the collections of the Finnish Museum of Natural History and those collected for the Finnish Game and Fisheries Research Institute were used in the present study. Only skulls of adult foxes ( $\geq 1 \mathrm{yr}$ ) were used. In total, there were 151 skulls ( 80 males and 71 females) from different localities of Finland. Skulls had been collected between 1885 and 2005. They came from two different geographic areas: Lapland and southern Finland (Fig. 1).

\section{Methods}

Nine cranial and 11 dental measurements were taken to the nearest $0.1 \mathrm{~mm}$ using a sliding cali- 
per. Due to pre or post mortem damage to bone or teeth it was not possible to take all the measurements from all the specimens. Measurements were taken by both authors. We did blind tests and found a good correlation between our measuring techniques.

Dental measurements taken were:

$\mathrm{C}_{1} \mathrm{~L}, \mathrm{C}_{1} \mathrm{~W}$ : the lower canine mesio-distal length and labio-lingual width at the base of the crown.

$\mathrm{M}_{1} \mathrm{~L}, \mathrm{M}_{1} \mathrm{~W}$ : mesio-distal length at the base of the crown and the greatest labio-lingual width of the lower carnassials.

$M_{1}$ trig: the mesio-distal length of the lower carnassial trigonid (formed by the three anterior cusps; protoconid, paraconid and metaconid).

$\mathrm{M}_{2} \mathrm{~L}$ : the mesio-distal length of the second lower molar.

$\mathrm{C}^{1} \mathrm{~L}, \mathrm{C}^{1} \mathrm{~W}$ : the upper canine mesio-distal length and labio-lingual width at the base of the crown.

$\mathrm{M}^{1} \mathrm{~L}, \mathrm{M}^{1} \mathrm{~W}$ : the mesio-distal length and the labio-lingual width at the base of the crown of the first upper molar.

\section{Cranial measurements taken:}

ZW: the widest point of the skull measured from the zygomatic arch to the other.

RB: rostral breadth measured between the lateral alveolar margins.

IC: interorbital constriction, the minimum distance between the two orbits.

PB: postorbital projection measurement between the posterior margins of the medial orbital walls.

PC: postorbital constriction or the narrowing between orbits and the braincase.

OCB: distance measured between the lateral margins of the occipital condyles.

ML: maximum mandibular length measured from the angular process to the mesial base of the lower incisors.

MW: minimum width of the mandibular ramus.

PL: profile length or the maximum length of the skull.

Individuals were coded for their spa-

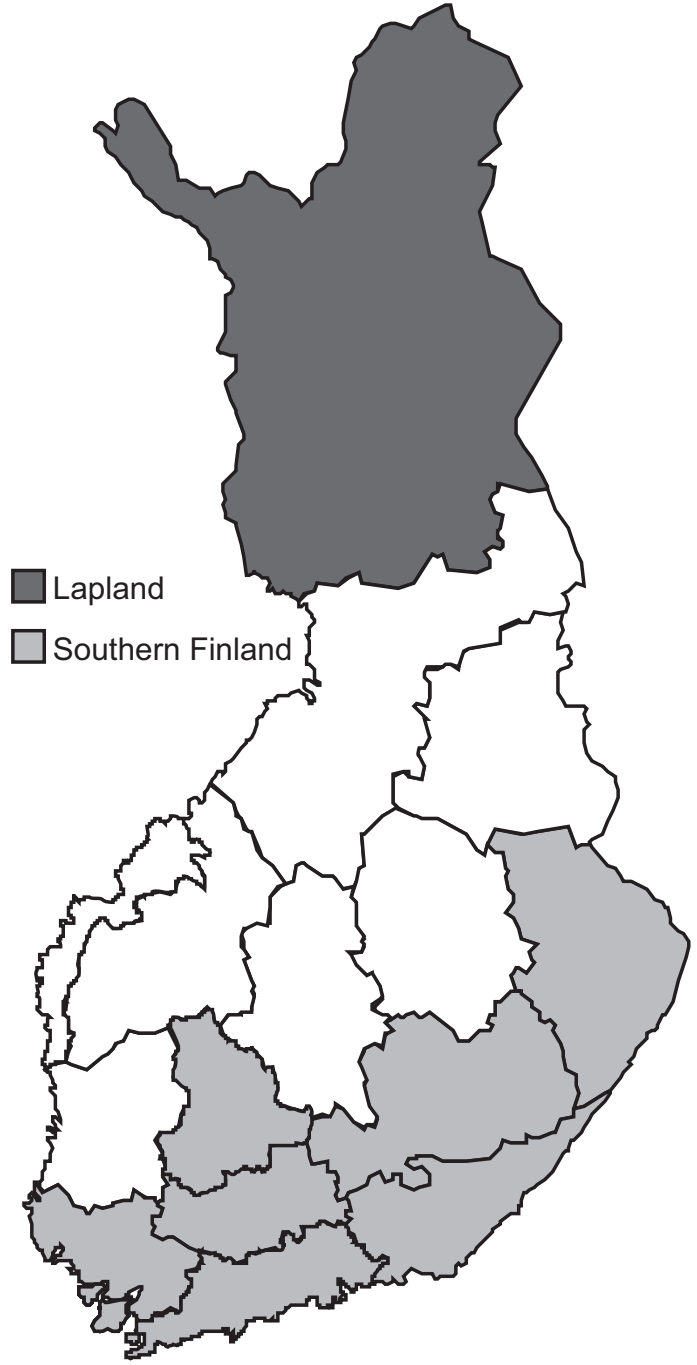

Fig. 1. Map of Finland showing the study areas.

tial occurrence, temporal occurrence and sex (Table 1). The spatial occurrence was coded as the locality (either from Lapland or southern Finland). For the temporal occurrence, animals which lived before 1970 were considered to belong to the pre-raccoon-dog population and the ones that were killed after 1970 were considered to belong to the post-raccoon-dog population. The year 1970 was chosen as a cut point, because prior to 1970 the raccoon dog population was scarce in Finland but increased rapidly thereafter (Helle \& Kauhala 1991).

In addition to the absolute measurements, relative measurements were used to study any 


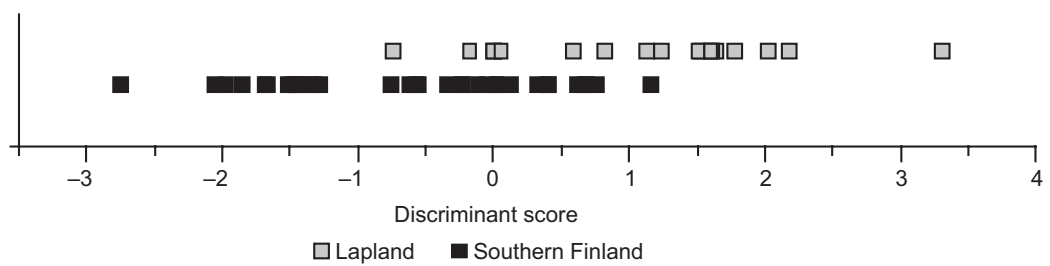

Fig. 2. Classification of the red foxes to Lappish and southern Finnish populations. Classification was done using the classical discriminant analysis with the cranial measurements of fox skulls as predictors. Canonical discriminant scores for each original skull are given.

possible morphological changes. For the relative dental measurements, the absolute measurements were divided by the lower carnassial length $\left(\mathrm{M}_{1} \mathrm{~L}\right)$ and, for the relative skull measurements, the absolute measurements were divided by OCB. As an index of the overall size we used PL.

We ran statistical tests using the commercial package of SYSTAT (ver. 12) and tested normality of the data distribution using a KolmogorovSmirnov one-sample test. We tested for differences in the morphology or size of skulls and teeth between the different groups and also differences in the sexual dimorphism in time or space using the $t$-test, paired $t$-test and the classical discriminant analysis (with jackknifed classification).

\section{Results}

Lappish red fox skulls were significantly larger than those from southern Finland. Mean skull length (PL) was $155.2 \mathrm{~mm}$ in Lapland and 147.9 $\mathrm{mm}$ in southern Finland $\left(t_{128}=4.11, p<0.001\right)$.

Table 1. Numbers of fox skulls from which cranial and dental measurements were taken for southern and Lappish populations.

\begin{tabular}{|c|c|c|c|c|c|}
\hline & \multicolumn{2}{|c|}{$\begin{array}{l}\text { Pre-raccoon-dog } \\
\text { period }\end{array}$} & \multicolumn{2}{|c|}{$\begin{array}{l}\text { Post-raccoon-dog } \\
\text { period }\end{array}$} & \multirow[b]{2}{*}{ Total } \\
\hline & Females & Males & Females & Males & \\
\hline \multicolumn{6}{|c|}{ Cranial measurements } \\
\hline Southern & 14 & 19 & 39 & 41 & 113 \\
\hline Lappish & 8 & 10 & - & - & 18 \\
\hline \multicolumn{6}{|c|}{ Dental measurements } \\
\hline Southern & 14 & 18 & 49 & 52 & 133 \\
\hline Lappish & 8 & 10 & - & - & 18 \\
\hline
\end{tabular}

Also the discriminant analysis with cranial measurements as predictors classified well the skulls as belonging to Lappish or southern populations (79\% correctly classified, Wilk's $\lambda=0.76, F_{9,107}$ $=3.8, p<0.001$; Fig. 2). Because of this and the fact that all the Lappish skulls were from the preraccoon-dog period, we decided to omit the Lappish material from the further testing. Because the male skulls were significantly longer than the female skulls (Table 2), we did all tests separately for males and females.

\section{Change in cranial and dental measurements}

There was no apparent skull-size change in the foxes after the arrival of the raccoon dog. In females, the mean skull length (PL) changed from $142.1 \mathrm{~mm}$ to $144.7 \mathrm{~mm}$, but this was not significant (Table 3). However, the difference in skull length between sexes has decreased from $10 \mathrm{~mm}$ to $6.2 \mathrm{~mm}$.

The discriminant analysis did not reveal any difference in the fox cranial morphology between the populations before and after the arrival of the raccoon dog (females: Wilk's $\lambda=0.85, F=0.70$, df $=9,36, p=0.699$, males: Wilk's $\lambda=0.79$, $F_{9,44}=1.30, p=0.262$; Fig. 3). Only RB ja IC increased among females (Table 3). Analyses of the relative measurements yielded similar results (females: Wilk's $\lambda=0.86, F_{8,37}=0.78, p$ $=0.626$, males: Wilk's $\lambda=0.81, F_{8,45}=1.37, p=$ $0.237)$. However, $76 \%$ of the female skulls were correctly classified by the discriminant analysis on the basis of dental characters as belonging to pre- or post-raccoon-dog population (Wilk's $\lambda$ $=0.43, F_{10,31}=4.1, p=0.001 ;$ Fig 3$) . \mathrm{C}_{1} \mathrm{~W}, \mathrm{M}_{1}$ trigonid, $\mathrm{M}_{2} \mathrm{~L}$ and $\mathrm{M}^{1} \mathrm{~W}$, were larger in females 
after the raccoon dog arrival (Table 4). The discriminant analysis could not classify the male skulls correctly (Wilk's $\lambda=0.68, F_{10,33}=1.6, p$ $=0.165)$. The classification of the female skulls on the basis of relative dental measurements was significant (Wilk's $\lambda=0.47, F_{9,32}=4.1, p=$ 0.002). Again, the discriminant analysis failed to classify the male skulls correctly (Wilk's $\lambda$ $\left.=0.70, F_{9.34}=1.6, p=0.144\right)$. Of the relative measurements, $\mathrm{M}_{1}$ trigonid, $\mathrm{M}_{2} \mathrm{~L}, \mathrm{C}^{1} \mathrm{~L}$ and $\mathrm{M}^{1} \mathrm{~W}$ of females were larger in the post-raccoon-dog population (Table 5). In the males, only the relative measurement of the trigonid had increased.

\section{Sexual dimorphism}

Sexual dimorphism was evident in the fox population from southern Finland (Table 2). The discriminant analysis with cranial measurements as predictors classified $77 \%$ of the skulls correctly according to sex (Wilk's $\lambda=0.54, F_{10,89}=7.7$,

Table 2. Finnish red fox cranial data from the pre- and post-raccoon-dog periods by sex. Number of specimens and the mean with SD of each measurement is given. A degree of sexual dimorphism (SP index) was calculated as a relation between the male measurement mean and the respective female measurement mean. Significance of the differences between the female and male measurements was tested using Student's $t$-test.

\begin{tabular}{|c|c|c|c|c|c|c|c|c|}
\hline & & $n$ & Mean $(\mathrm{mm})$ & SD & SP index & $t$ & df & $p$ \\
\hline \multicolumn{9}{|c|}{ Pre-raccoon-dog period } \\
\hline \multirow[t]{2}{*}{$\mathrm{PL}$} & Female & 14 & 142.1 & 5.79 & 1.07 & -5.25 & 31 & $<0.001$ \\
\hline & Male & 19 & 152.1 & 5.09 & & & & \\
\hline \multirow[t]{2}{*}{$Z W$} & Female & 14 & 76.0 & 3.15 & 1.03 & -2.04 & 31 & 0.050 \\
\hline & Male & 19 & 78.4 & 3.46 & & & & \\
\hline \multirow[t]{2}{*}{$\mathrm{RB}$} & Female & 14 & 23.1 & 1.52 & 1.08 & -3.7 & 31 & 0.001 \\
\hline & Male & 19 & 24.9 & 1.27 & & & & \\
\hline \multirow[t]{2}{*}{ IC } & Female & 14 & 26.7 & 2.57 & 1.08 & -3.01 & 31 & 0.005 \\
\hline & Male & 19 & 28.9 & 1.50 & & & & \\
\hline \multirow[t]{2}{*}{ PB } & Female & 14 & 35.5 & 3.15 & 1.05 & -1.48 & 31 & 0.150 \\
\hline & Male & 19 & 37.1 & 3.33 & & & & \\
\hline \multirow{2}{*}{$\mathrm{PC}$} & Female & 14 & 23.4 & 1.26 & 0.98 & 0.72 & 31 & 0.478 \\
\hline & Male & 19 & 22.9 & 1.91 & & & & \\
\hline \multirow[t]{2}{*}{ ОСВ } & Female & 14 & 25.7 & 1.09 & 1.04 & -3.39 & 31 & 0.002 \\
\hline & Male & 19 & 26.7 & 0.62 & & & & \\
\hline \multirow[t]{2}{*}{ ML } & Female & 14 & 103.4 & 7.72 & 1.07 & -3.52 & 31 & 0.001 \\
\hline & Male & 19 & 110.7 & 4.13 & & & & \\
\hline \multirow[t]{2}{*}{ MW } & Female & 14 & 14.9 & 1.04 & 1.11 & -5.01 & 31 & $<0.001$ \\
\hline & Male & 19 & 16.5 & 0.85 & & & & \\
\hline \multicolumn{9}{|c|}{ Post-raccoon-dog period } \\
\hline \multirow[t]{2}{*}{ PL } & Female & 38 & 144.7 & 5.39 & 1.04 & -4.85 & 77 & $<0.001$ \\
\hline & Male & 41 & 150.9 & 5.89 & & & & \\
\hline \multirow[t]{2}{*}{ ZW } & Female & 36 & 76.5 & 2.74 & 1.05 & -4.65 & 70 & $<0.001$ \\
\hline & Male & 36 & 80.0 & 3.53 & & & & \\
\hline \multirow[t]{2}{*}{ RB } & Female & 39 & 23.9 & 1.01 & 1.04 & -3.33 & 77 & 0.001 \\
\hline & Male & 40 & 24.8 & 1.34 & & & & \\
\hline \multirow[t]{2}{*}{ IC } & Female & 38 & 28.0 & 1.59 & 1.05 & -3.23 & 77 & 0.002 \\
\hline & Male & 41 & 29.3 & 1.88 & & & & \\
\hline \multirow[t]{2}{*}{ PB } & Female & 37 & 36.5 & 2.99 & 1.04 & -2.25 & 75 & 0.027 \\
\hline & Male & 40 & 38.0 & 2.66 & & & & \\
\hline \multirow[t]{2}{*}{ PC } & Female & 38 & 23.1 & 1.76 & 0.99 & 0.88 & 77 & 0.381 \\
\hline & Male & 41 & 22.7 & 1.64 & & & & \\
\hline \multirow[t]{2}{*}{ ОСВ } & Female & 37 & 25.9 & 0.93 & 1.04 & -4.27 & 73 & $<0.001$ \\
\hline & Male & 38 & 26.8 & 1.06 & & & & \\
\hline \multirow[t]{2}{*}{$\mathrm{ML}$} & Female & 38 & 106.2 & 4.56 & 1.04 & -3.67 & 77 & $<0.001$ \\
\hline & Male & 41 & 110.2 & 5.12 & & & & \\
\hline \multirow[t]{2}{*}{ MW } & Female & 39 & 15.3 & 0.81 & 1.07 & -5.1 & 78 & $<0.001$ \\
\hline & Male & 41 & 16.3 & 0.95 & & & & \\
\hline
\end{tabular}


$p<0.001)$. Sexual dimorphism was evident both before and after the raccoon dog arrival (before: $76 \%$ correct, Wilk's $\lambda=0.27, F_{9.23}=6.8, p<$ 0.001 ; after: $75 \%$ correct, Wilk's $\lambda=0.59, F_{9,57}$ $=4.5, p<0.001)$. The discriminant analysis with dental measurements as predictors also revealed sexual dimorphism in the fox populations both before and after the raccoon dog arrival (before: $70 \%$ correct, Wilk's $\lambda=0.39, F_{10,19}=3.0, p=$ 0.019 , after: $75 \%$ correct, Wilk's $\lambda=0.53, F_{10,45}$ $=4.1, p=0.001)$.
Throughout the data, most of the cranial and dental measurements were significantly larger in males than in females (Tables 2 and 6). Of the individual cranial measurements, all but the postorbital constriction (PC) were significantly larger in males (and $\mathrm{PB}$ in pre raccoon dog population). Of the dental measurements, all but $\mathrm{M}_{1} \mathrm{~W}, \mathrm{M}_{2} \mathrm{~L}$ and $\mathrm{C}^{1} \mathrm{~L}$ in pre raccoon dog population, and both postcarnassial teeth $\left(\mathrm{M}^{1} \mathrm{~L}\right.$ and $\mathrm{M}_{2} \mathrm{~L}$ ) in post raccoon dog population were significantly larger in males (Table 6).

Table 3. Differences in the cranial measurements between pre- and post-raccoon-dog populations of Finnish foxes. The mean and SD of each measurement is given along with the results of Student's $t$-test.

\begin{tabular}{|c|c|c|c|c|c|c|c|}
\hline & & $n$ & Mean $(\mathrm{mm})$ & $\mathrm{SD}$ & $t$ & $d f$ & $p$ \\
\hline \multicolumn{8}{|c|}{ Females } \\
\hline \multirow[t]{2}{*}{ PL } & pre & 14 & 142.1 & 5.79 & -1.48 & 50 & 0.145 \\
\hline & post & 38 & 144.7 & 5.39 & & & \\
\hline \multirow[t]{2}{*}{ ZW } & pre & 14 & 76.0 & 3.15 & -0.52 & 48 & 0.607 \\
\hline & post & 36 & 76.5 & 2.74 & & & \\
\hline \multirow[t]{2}{*}{ RB } & pre & 14 & 23.1 & 1.52 & -2.28 & 51 & 0.027 \\
\hline & post & 39 & 23.9 & 1.01 & & & \\
\hline \multirow[t]{2}{*}{ IC } & pre & 14 & 26.7 & 2.57 & -2.21 & 50 & 0.032 \\
\hline & post & 38 & 28.0 & 1.59 & & & \\
\hline \multirow[t]{2}{*}{ PB } & pre & 14 & 35.5 & 3.15 & -1.14 & 49 & 0.261 \\
\hline & post & 37 & 36.5 & 2.99 & & & \\
\hline \multirow[t]{2}{*}{$\mathrm{PC}$} & pre & 14 & 23.4 & 1.26 & 0.58 & 50 & 0.564 \\
\hline & post & 38 & 23.1 & 1.76 & & & \\
\hline \multirow[t]{2}{*}{ OCB } & pre & 14 & 25.7 & 1.09 & -0.61 & 49 & 0.548 \\
\hline & post & 37 & 25.9 & 0.93 & & & \\
\hline \multirow[t]{2}{*}{$\mathrm{ML}$} & pre & 14 & 103.4 & 7.72 & -0.61 & 49 & 0.548 \\
\hline & post & 38 & 106.2 & 4.56 & & & \\
\hline \multirow[t]{2}{*}{ MW } & pre & 14 & 14.9 & 1.04 & -1.7 & 51 & 0.095 \\
\hline & post & 39 & 15.3 & 0.81 & & & \\
\hline \multicolumn{8}{|l|}{ Males } \\
\hline \multirow[t]{2}{*}{ PL } & pre & 19 & 152.1 & 5.09 & 0.79 & 58 & 0.433 \\
\hline & post & 41 & 150.9 & 5.89 & & & \\
\hline \multirow[t]{2}{*}{$Z W$} & pre & 19 & 78.4 & 3.46 & -1.54 & 53 & 0.130 \\
\hline & post & 36 & 80.0 & 3.53 & & & \\
\hline \multirow[t]{2}{*}{$\mathrm{RB}$} & pre & 19 & 24.9 & 1.27 & 0.31 & 57 & 0.758 \\
\hline & post & 40 & 24.8 & 1.34 & & & \\
\hline \multirow[t]{2}{*}{ IC } & pre & 19 & 28.9 & 1.5 & -0.83 & 58 & 0.412 \\
\hline & post & 41 & 29.3 & 1.88 & & & \\
\hline \multirow[t]{2}{*}{ PB } & pre & 19 & 37.1 & 3.33 & -1.04 & 57 & 0.302 \\
\hline & post & 40 & 38.0 & 2.66 & & & \\
\hline \multirow[t]{2}{*}{ PC } & pre & 19 & 22.9 & 1.91 & 0.45 & 58 & 0.658 \\
\hline & post & 41 & 22.7 & 1.64 & & & \\
\hline \multirow[t]{2}{*}{ ОСВ } & pre & 19 & 26.7 & 0.62 & -0.56 & 55 & 0.578 \\
\hline & post & 38 & 26.8 & 1.06 & & & \\
\hline \multirow[t]{2}{*}{$M L$} & pre & 19 & 110.7 & 4.13 & 0.34 & 58 & 0.733 \\
\hline & post & 41 & 110.2 & 5.12 & & & \\
\hline \multirow[t]{2}{*}{ MW } & pre & 19 & 16.5 & 0.85 & 0.71 & 58 & 0.481 \\
\hline & post & 41 & 16.3 & 0.95 & & & \\
\hline
\end{tabular}



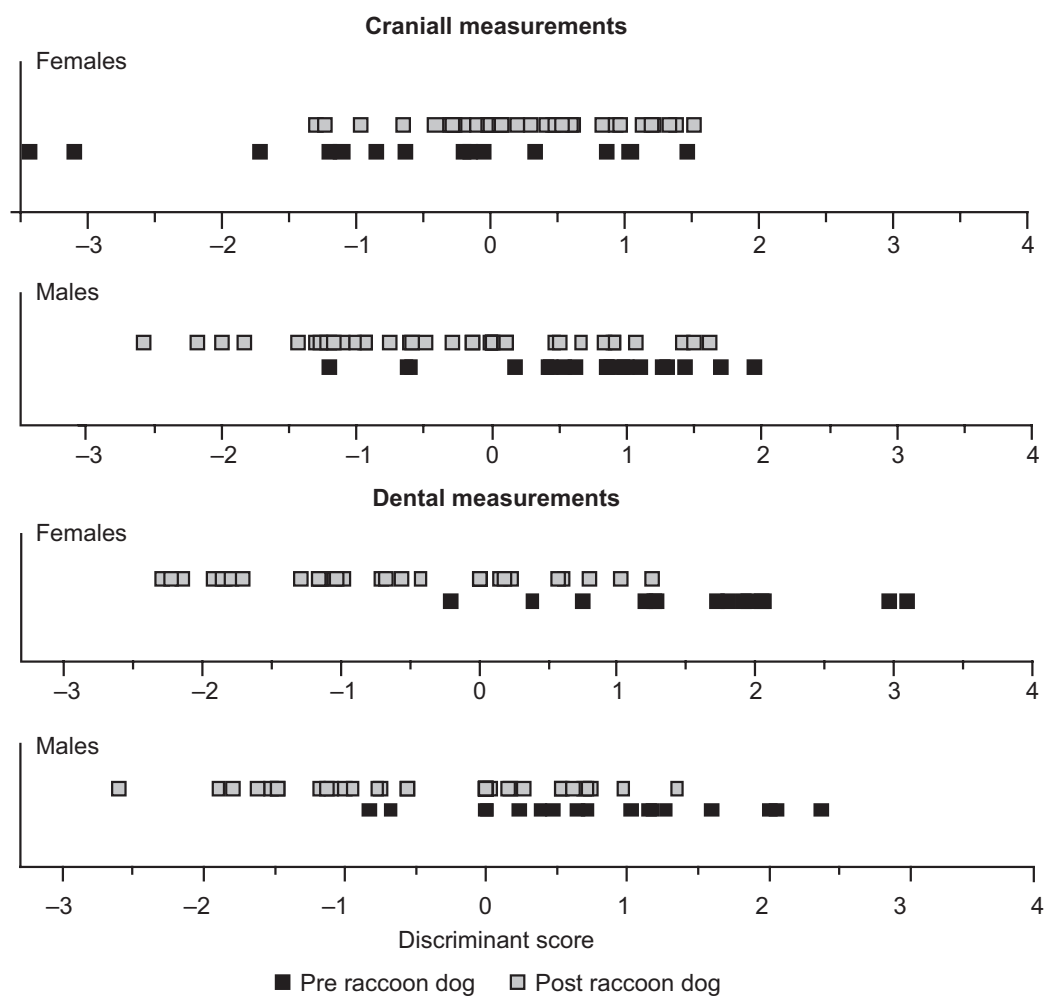

Fig. 3. Classification of the red foxes to pre- and post-raccoon-dog populations. Classification was done using the classical discriminant analysis with cranial and dental measurements of fox skulls as predictors. Canonical discriminant scores for each original skull are given. Females and males were analysed separately.

A paired $t$-test on the sexual dimorphism indices suggested a small difference toward decreased dimorphism (for cranial measurements $t_{8}=2.23, p=0.056$; for dental measurements $\left.t_{9}=2.39, p=0.040\right)$. In the dental material, the mean SP index was 1.067 and 1.038 for the pre-and post-raccoon-dog populations, respectively. In the cranial material, the mean SP index was 1.057 and 1.040 for the pre-and postraccoon-dog populations, respectively. Except for ZW and PC, the SP index decreased for all other individual skull measurements. In the dental characters, the SP index decreased in all measurements except for $\mathrm{M}_{1} \mathrm{~W}$ and $\mathrm{C}^{1} \mathrm{~L}$.

\section{Discussion}

\section{Change in size}

We predicted larger sizes for the Lappish foxes.
Our results were in accordance with the prediction and with Bergmann's rule showing that the Lappish skulls were larger than those from southern Finland. Szuma (2008b) also found the largest Holarctic foxes (as measured from total skull length and lower carnassial length) from Scandinavia. Finnish foxes were not included in her study, but our results showed that their medians were very close to those of the largest foxes from northern Eurasia. Against our prediction, we did not record any significant skull size change in the red fox in southern Finland from pre- and post-raccoon-dog populations (Table 3 ).

\section{Morphological change}

We predicted that competition with a more omnivorous carnivore would lead to more hypercarnivorous traits in the dentition and cranial characters in the red fox. Indeed, our data indicated pro- 
nounced hypercarnivory with enlarged trigonid and increased rostral width after the arrival of raccoon dogs. The changes were more marked in females than in males (Table 4). The rostral width showed no increase in males (Table 3 ).

Yom-Tov et al. (2003) showed that many dental and cranial characters of the Danish foxes increased in size during the 20th century although the total skull length show no change, indicating the change in morphotype not in the overall size. The authors attributed the change to wider dietary range due to increased commensalism with humans. Ecological studies have indicated a similar trend towards commensalism with humans in the behavior of the Finnish foxes (Lappalainen \& Vuorisalo 1996), but this is not relevant to our study which included skulls of foxes collected mainly from rural areas.

Table 4. Differences in the dental measurements between pre- and post-raccoon-dog populations of Finnish foxes. The mean and SD of each measurement is given along with the results of Student's $t$-test.

\begin{tabular}{|c|c|c|c|c|c|c|c|}
\hline & & $n$ & Mean $(\mathrm{mm})$ & SD & $t$ & df & $p$ \\
\hline \multicolumn{8}{|l|}{ Females } \\
\hline \multirow[t]{2}{*}{$\mathrm{C}_{1} \mathrm{~L}$} & pre & 14 & 7.0 & 0.84 & 0.53 & 42 & 0.602 \\
\hline & post & 30 & 6.9 & 0.65 & & & \\
\hline \multirow[t]{2}{*}{$\mathrm{C}_{1} \mathrm{~W}$} & pre & 14 & 4.4 & 0.45 & -2.06 & 42 & 0.046 \\
\hline & post & 30 & 4.7 & 0.33 & & & \\
\hline \multirow[t]{2}{*}{$M_{1} L$} & pre & 14 & 15.4 & 0.88 & -1.24 & 61 & 0.221 \\
\hline & post & 49 & 15.7 & 0.73 & & & \\
\hline \multirow[t]{2}{*}{$\mathrm{M}_{1} \mathrm{~W}$} & pre & 14 & 6.3 & 0.62 & 0.87 & 61 & 0.386 \\
\hline & post & 49 & 6.2 & 0.33 & & & \\
\hline \multirow[t]{2}{*}{$M_{1}$ trig } & pre & 14 & 10.6 & 0.56 & -2.53 & 61 & 0.014 \\
\hline & post & 49 & 11.0 & 0.59 & & & \\
\hline \multirow[t]{2}{*}{$\mathrm{M}_{2} \mathrm{~L}$} & pre & 14 & 6.9 & 0.53 & -3.31 & 61 & 0.003 \\
\hline & post & 49 & 7.4 & 0.53 & & & \\
\hline \multirow[t]{2}{*}{$C^{1} \mathrm{~L}$} & pre & 14 & 7.0 & 0.51 & 1.97 & 40 & 0.056 \\
\hline & post & 28 & 6.7 & 0.53 & & & \\
\hline \multirow[t]{2}{*}{$\mathrm{C}^{1} \mathrm{~W}$} & pre & 14 & 4.4 & 0.32 & 0 & 40 & 1.000 \\
\hline & post & 28 & 4.4 & 0.29 & & & \\
\hline \multirow[t]{2}{*}{$M^{1} L$} & pre & 14 & 9.8 & 0.65 & -1.31 & 61 & 0.196 \\
\hline & post & 49 & 10.0 & 0.48 & & & \\
\hline \multirow[t]{2}{*}{$M^{1} W$} & pre & 14 & 11.1 & 0.78 & -3.24 & 61 & 0.002 \\
\hline & post & 49 & 11.7 & 0.56 & & & \\
\hline \multicolumn{8}{|l|}{ Males } \\
\hline \multirow[t]{2}{*}{$C_{1} \mathrm{~L}$} & pre & 18 & 7.7 & 0.7 & 2.04 & 47 & 0.047 \\
\hline & post & 31 & 7.4 & 0.57 & & & \\
\hline \multirow[t]{2}{*}{$\mathrm{C}_{1} \mathrm{~W}$} & pre & 18 & 5.0 & 0.4 & 1.45 & 47 & 0.155 \\
\hline & post & 31 & 4.9 & 0.3 & & & \\
\hline \multirow[t]{2}{*}{$M_{1} L$} & pre & 18 & 16.4 & 0.86 & 0.34 & 68 & 0.734 \\
\hline & post & 52 & 16.3 & 0.93 & & & \\
\hline \multirow[t]{2}{*}{$M_{1} W$} & pre & 18 & 6.5 & 0.31 & -0.22 & 68 & 0.824 \\
\hline & post & 52 & 6.5 & 0.3 & & & \\
\hline \multirow[t]{2}{*}{$M_{1}$ trig } & pre & 18 & 11.2 & 0.67 & -1.46 & 68 & 0.149 \\
\hline & post & 52 & 11.6 & 0.91 & & & \\
\hline \multirow[t]{2}{*}{$\mathrm{M}_{2} \mathrm{~L}$} & pre & 16 & 7.2 & 0.53 & -1.83 & 66 & 0.072 \\
\hline & post & 52 & 7.5 & 0.49 & & & \\
\hline \multirow[t]{2}{*}{$C^{1} L$} & pre & 18 & 7.2 & 0.34 & 1.19 & 44 & 0.240 \\
\hline & post & 28 & 7.0 & 0.52 & & & \\
\hline \multirow[t]{2}{*}{$\mathrm{C}^{1} \mathrm{~W}$} & pre & 18 & 4.7 & 0.34 & 0.48 & 44 & 0.637 \\
\hline & post & 28 & 4.7 & 0.33 & & & \\
\hline \multirow[t]{2}{*}{$M^{1} L$} & pre & 18 & 10.4 & 0.62 & 1.3 & 67 & 0.191 \\
\hline & post & 51 & 10.2 & 0.42 & & & \\
\hline \multirow[t]{2}{*}{$\mathrm{M}^{1} \mathrm{~W}$} & pre & 18 & 12.2 & 0.53 & 0.03 & 67 & 0.980 \\
\hline & post & 51 & 12.1 & 0.77 & & & \\
\hline
\end{tabular}




\section{Sexual dimorphism}

We predicted increased sexual dimorphism due to competition between the raccoon dog and the red fox. Similar to earlier studies (Dayan et al. 1992, Szuma 2008a), we found existing sexual dimorphism in most of the studied characters. Interestingly, sexual dimorphism - especially in teeth size - decreased in the population co-existing with the raccoon dog (Table 2). We suggest that increased competition with raccoon dogs resulted in increased dental size in females, but not in males leading to lesser degree of dimorphism. Perhaps the diet of smaller female foxes overlapped more with the diet of raccoon dogs than did the diet of larger male foxes.

We also found that the change in sexual dimorphism was greater in some characters than others (Table 2). In the pre-raccoon-dog population, fox canines showed higher degree of sexual dimorphism than found for the red fox in earlier studies (Szuma 2008a), but in the post-raccoon-dog pop-

Table 5. Differences in the relative dental measurements between pre- and post-raccoon-dog populations of Finnish foxes. The relative measurements were obtained by dividing the actual measurements by $M_{1} L$. The mean and $\mathrm{SD}$ of each measurement is given along with the results of Student's $t$-test.

\begin{tabular}{|c|c|c|c|c|c|c|c|}
\hline & & $n$ & Mean $(\mathrm{mm})$ & $\mathrm{SD}$ & $t$ & $\mathrm{df}$ & $p$ \\
\hline \multicolumn{8}{|l|}{ Females } \\
\hline \multirow[t]{2}{*}{$C_{1} L$} & pre & 14 & 0.46 & 0.05 & 1.28 & 42 & 0.206 \\
\hline & post & 30 & 0.44 & 0.04 & & & \\
\hline \multirow[t]{2}{*}{$C_{1} W$} & pre & 14 & 0.29 & 0.03 & -1.20 & 42 & 0.237 \\
\hline & post & 30 & 0.3 & 0.02 & & & \\
\hline \multirow[t]{2}{*}{$\mathrm{M}_{1} \mathrm{~W}$} & pre & 14 & 0.41 & 0.04 & 1.93 & 61 & 0.059 \\
\hline & post & 49 & 0.4 & 0.02 & & & \\
\hline \multirow[t]{2}{*}{$\mathrm{M}_{1}$ trig } & pre & 14 & 0.69 & 0.04 & -1.74 & 61 & 0.014 \\
\hline & post & 49 & 0.7 & 0.03 & & & \\
\hline \multirow[t]{2}{*}{$M_{2} L$} & pre & 14 & 0.45 & 0.04 & -2.49 & 61 & 0.015 \\
\hline & post & 49 & 0.47 & 0.02 & & & \\
\hline \multirow[t]{2}{*}{$C^{1} \mathrm{~L}$} & pre & 14 & 0.46 & 0.03 & 3.16 & 40 & 0.003 \\
\hline & post & 28 & 0.43 & 0.03 & & & \\
\hline \multirow[t]{2}{*}{$\mathrm{C}^{1} \mathrm{~W}$} & pre & 14 & 0.28 & 0.02 & 0.8 & 40 & 0.429 \\
\hline & post & 28 & 0.28 & 0.02 & & & \\
\hline \multirow[t]{2}{*}{$M^{1} L$} & pre & 14 & 0.64 & 0.04 & -0.17 & 61 & 0.869 \\
\hline & post & 49 & 0.64 & 0.03 & & & \\
\hline \multirow[t]{2}{*}{$M^{1} W$} & pre & 14 & 0.72 & 0.05 & -2.29 & 61 & 0.025 \\
\hline & post & 49 & 0.75 & 0.03 & & & \\
\hline \multicolumn{8}{|l|}{ Males } \\
\hline \multirow[t]{2}{*}{$C_{1} L$} & pre & 18 & 0.47 & 0.04 & 0.99 & 47 & 0.328 \\
\hline & post & 31 & 0.45 & 0.06 & & & \\
\hline \multirow[t]{2}{*}{$\mathrm{C}_{1} \mathrm{~W}$} & pre & 18 & 0.31 & 0.02 & 0.48 & 47 & 0.631 \\
\hline & post & 31 & 0.3 & 0.03 & & & \\
\hline \multirow[t]{2}{*}{$M_{1} W$} & pre & 18 & 0.4 & 0.02 & -0.57 & 68 & 0.570 \\
\hline & post & 52 & 0.4 & 0.02 & & & \\
\hline \multirow[t]{2}{*}{$\mathrm{M}_{1}$ trig } & pre & 18 & 0.69 & 0.03 & -2.87 & 68 & 0.005 \\
\hline & post & 52 & 0.71 & 0.03 & & & \\
\hline \multirow[t]{2}{*}{$\mathrm{M}_{2} \mathrm{~L}$} & pre & 16 & 0.45 & 0.03 & -1.34 & 66 & 0.186 \\
\hline & post & 52 & 0.46 & 0.05 & & & \\
\hline \multirow[t]{2}{*}{$\mathrm{C}^{1} \mathrm{~L}$} & pre & 18 & 0.44 & 0.02 & 0.29 & 44 & 0.776 \\
\hline & post & 28 & 0.44 & 0.05 & & & \\
\hline \multirow[t]{2}{*}{$C^{1} W$} & pre & 18 & 0.29 & 0.02 & -0.22 & 44 & 0.831 \\
\hline & post & 28 & 0.29 & 0.03 & & & \\
\hline \multirow[t]{2}{*}{$M^{1} L$} & pre & 18 & 0.63 & 0.03 & 0.54 & 67 & 0.592 \\
\hline & post & 51 & 0.63 & 0.04 & & & \\
\hline \multirow[t]{2}{*}{$M^{1} W$} & pre & 18 & 0.75 & 0.04 & -0.03 & 67 & 0.800 \\
\hline & post & 51 & 0.75 & 0.06 & & & \\
\hline
\end{tabular}


ulation dimorphism dropped to the average level of the Palearctic region. Earlier studies (Szuma 2007) showed the highest sexual dimorphism in fox canines in England where foxes are not highly dimorphic in other traits such as the carnassials. They are the only canid species on the island, but occur at high densities. English foxes often are city dwellers that tend to form social groups
(Harris \& Baker 2001). It is difficult to address the cause of the decreased sexual dimorphism of canines without any ecological data of the possible change in social behaviour in Finnish fox.

The sexual dimorphism of the lower carnassials has been shown to correlate with sympatry of the red fox with other Vulpes species (Szuma 2008a). In our study, sympatry with the raccoon

Table 6. Finnish red fox dental data for the pre- and post-raccoon-dog populations by sex. Number of specimens and the mean with SD of each measurement is given. The degree of sexual dimorphism (SP index) was calculated as a relation between the male measurement mean and the respective female measurement mean. Significance of the difference between the female and male measurements was tested using Student's $t$-test.

\begin{tabular}{|c|c|c|c|c|c|c|c|c|}
\hline & & $n$ & Mean (mm) & SD & SP index & $t$ & $\mathrm{df}$ & $p$ \\
\hline \multicolumn{9}{|c|}{ Pre-raccoon-dog period } \\
\hline \multirow[t]{2}{*}{$C_{1} L$} & Female & 14 & 7.0 & 0.84 & 1.10 & -2.6 & 30 & 0.014 \\
\hline & Male & 18 & 7.7 & 0.7 & & & & \\
\hline \multirow[t]{2}{*}{$C_{1} W$} & Female & 14 & 4.4 & 0.44 & 1.13 & -3.83 & 30 & 0.001 \\
\hline & Male & 18 & 5.0 & 0.4 & & & & \\
\hline \multirow[t]{2}{*}{$M_{1} L$} & Female & 14 & 15.4 & 0.88 & 1.06 & -3.05 & 30 & 0.005 \\
\hline & Male & 18 & 16.3 & 0.86 & & & & \\
\hline \multirow[t]{2}{*}{$M_{1} W$} & Female & 14 & 6.3 & 0.62 & 1.03 & -0.97 & 30 & 0.340 \\
\hline & Male & 18 & 6.5 & 0.31 & & & & \\
\hline \multirow[t]{2}{*}{$\mathrm{M}_{1}$ trig } & Female & 14 & 10.6 & 0.56 & 1.06 & -2.88 & 30 & 0.007 \\
\hline & Male & 18 & 11.2 & 0.67 & & & & \\
\hline \multirow[t]{2}{*}{$M_{2} L$} & Female & 14 & 6.9 & 0.53 & 1.03 & -1.52 & 28 & 0.140 \\
\hline & Male & 16 & 7.2 & 0.53 & & & & \\
\hline \multirow[t]{2}{*}{$C^{1} L$} & Female & 14 & 7.0 & 0.51 & 1.03 & -1.19 & 30 & 0.242 \\
\hline & Male & 18 & 7.2 & 0.34 & & & & \\
\hline \multirow[t]{2}{*}{$\mathrm{C}^{1} \mathrm{~W}$} & Female & 14 & 4.4 & 0.29 & 1.07 & -3.4 & 30 & 0.002 \\
\hline & Male & 18 & 4.7 & 0.34 & & & & \\
\hline \multirow[t]{2}{*}{$M^{1} L$} & Female & 14 & 9.8 & 0.65 & 1.06 & -2.35 & 30 & 0.026 \\
\hline & Male & 18 & 10.4 & 0.62 & & & & \\
\hline \multirow[t]{2}{*}{$M^{1} W$} & Female & 14 & 11.1 & 0.78 & 1.10 & -4.41 & 30 & $<0.001$ \\
\hline & Male & 18 & 12.2 & 0.53 & & & & \\
\hline \multicolumn{9}{|c|}{ Post-raccoon-dog period } \\
\hline \multirow[t]{2}{*}{$\mathrm{C}_{1} \mathrm{~L}$} & Female & 30 & 6.9 & 0.65 & 1.07 & -2.9 & 59 & 0.005 \\
\hline & Male & 31 & 7.4 & 0.57 & & & & \\
\hline \multirow[t]{2}{*}{$C_{1} W$} & Female & 30 & 4.7 & 0.33 & 1.04 & -2.28 & 59 & 0.026 \\
\hline & Male & 31 & 4.9 & 0.31 & & & & \\
\hline \multirow[t]{2}{*}{$M_{1} L$} & Female & 49 & 15.7 & 0.73 & 1.03 & -3.44 & 99 & 0.001 \\
\hline & Male & 52 & 16.3 & 0.93 & & & & \\
\hline \multirow[t]{2}{*}{$M_{1} W$} & Female & 49 & 6.2 & 0.33 & 1.05 & -4.67 & 99 & $<0.001$ \\
\hline & Male & 52 & 6.5 & 0.3 & & & & \\
\hline \multirow[t]{2}{*}{$M_{1}$ trig } & Female & 49 & 11.0 & 0.59 & 1.05 & -3.54 & 99 & 0.001 \\
\hline & Male & 52 & 11.6 & 0.91 & & & & \\
\hline \multirow[t]{2}{*}{$M_{2} L$} & Female & 49 & 7.4 & 0.53 & 1.01 & -0.55 & 99 & 0.586 \\
\hline & Male & 52 & 7.5 & 0.49 & & & & \\
\hline \multirow[t]{2}{*}{$C^{1} L$} & Female & 28 & 6.7 & 0.54 & 1.04 & -2.52 & 54 & 0.015 \\
\hline & Male & 28 & 7.0 & 0.52 & & & & \\
\hline \multirow[t]{2}{*}{$\mathrm{C}^{1} \mathrm{~W}$} & Female & 28 & 4.4 & 0.32 & 1.07 & -3.9 & 54 & $<0.001$ \\
\hline & Male & 28 & 4.7 & 0.33 & & & & \\
\hline \multirow[t]{2}{*}{$M^{1} L$} & Female & 49 & 10.0 & 0.48 & 1.02 & -1.67 & 98 & 0.098 \\
\hline & Male & 51 & 10.2 & 0.42 & & & & \\
\hline \multirow[t]{2}{*}{$M^{1} W$} & Female & 49 & 11.7 & 0.56 & 1.03 & -3.1 & 98 & 0.003 \\
\hline & Male & 51 & 12.1 & 0.77 & & & & \\
\hline
\end{tabular}


dog in Finland had an opposite effect, i.e. size dimorphism decreased in the fox (Table 2). The most significant discriminating factor in Szuma's study was dimorphism increase in the $\mathrm{M}_{1}$ length. Again our results contradicted those of Szuma's as the sympatrism with the raccoon dog resulted in dimorphism decrease in the $\mathrm{M}_{1}$ length in the red fox.

\section{Conclusions}

Competition for food resources between vixens and raccoon dogs may be heavier than competition between male foxes and raccoon dogs. It is possible that the diet of female foxes has been closer to that of raccoon dogs whereas, even before the arrival of the raccoon dog, fox males had been more carnivorous and hunted larger prey than raccoon dogs were capable of catching. During the breeding season, both parents hunt larger prey for the pups but consume smaller prey themselves (Lindström 1994). The breeding season is a time of intense competition and selection. The absolute increase in size of female teeth and trigonid may be a requirement for acquiring enough food for pups.

Finnish foxes may be specializing on larger prey such as hares (Lepus sp.) and the young of roe deer (Capreolus capreolus) (Jarnemo \& Liberg 2005). If the foxes' survival or survival of pups were enhanced by better adaptations to predation on larger prey, then the ones with more carnivorous bite would be favored by natural selection.

In the light of previous dietary studies and our observations on morphology, we conclude that the Finnish red foxes (but mainly the vixens) are becoming more hypercarnivorous. This is possibly a response to the arrival of a new carnivore. However, changes in the prey composition or other environmental changes cannot be ruled out, and may contribute or be completely responsible for the change.

\section{Acknowledgments}

We are grateful to hunters who provided carcasses for the Finnish Game and Fisheries Research Institute and Ritva
Koivunen for cleaning the skulls. We also thank Ilpo Hanski for providing access to the skulls housed in the Finnish Museum of Natural History.

\section{References}

Baker, P. J. \& Harris, S. 2004: Red foxes. The behavioural ecology of red foxes in urban Bristol. - In: Macdonald, D. W. \& Sillero-Zubiri, C. (eds.), Biology and conservation of wild canids: 207-216. Oxford University Press, Oxford.

Brown, W. L. Jr. \& Wilson, E. O. 1956: Character displacement. - Systematic Zoology 5: 49-64.

Davies, T. J., Meiri, S., Barraclough, T. G. \& Gittleman, J. 2007: Species co-existence and character divergence across carnivores. - Ecology Letters 10: 146-152.

Dayan, T. D., Tchernov, E., Yom-Tov, Y. \& Simberloff, E. 1989: Ecological character displacement in SaharoArabian foxes: outfoxing the Bergmann's rule. - Oikos 55: $363-372$.

Dayan, T. D., Simberloff, E., Tchernov, E. \& Yom-Tov, Y. 1992: Canine carnassials: character displacement in the wolves, jackals and foxes of Israel. - Biological Journal of Linnean Society 45: 315-331.

Friscia, A. R., Van Valkenburgh, B. \& Bicnevicius, A. R. 2007: An ecomophological analysis of extant small carnivorans. - Journal Zoology, London 272: 82-100.

Harris, S. \& Baker, P. 2001: Urban foxes. - Whittet Books, Suffolk, UK

Helle, E. \& Kauhala, K. 1991: Distribution history and present status of the raccoon dog in Finland. - Holarctic Ecology 14: 278-286.

Holmala, K. \& Kauhala, K. 2009: Habitat use of mediumsized carnivores in southeast Finland - key habitats for rabies spread? - Annales Zoologici Fennici 46: 233-246.

Jarnemo, A. \& Liberg, O. 2005: Red fox removal and roe deer fawn survival: a 14-year study. - The Journal of Wildlife Management 69: 1090-1098.

Kauhala, K. 1993: Growth, size, and fat reserves of the raccoon dog in Finland. - Acta Theriologica 38: 139-150.

Kauhala, K. 2004: Removal of medium-sized predators and the breeding success of ducks in Finland. - Folia Zoologica 53: 367-378.

Kauhala, K., Holmala, K., Lammers, W. \& Schregel, J. 2006: Home ranges and densities of medium-sized carnivores in south-east Finland, with special reference to rabies spread. - Acta Theriologica 51: 1-13.

Kauhala, K., Laukkanen, P. \& von Rége, I. 1998: Summer food composition and food niche overlap of the raccoon dog, red fox and badger in Finland. - Ecography 21: 457-463.

Larivière, S. \& Pasitschniak-Arts, M. 1996: Vulpes vulpes. - Mammalian Species 537: 1-11.

Lavrov N. Р. [Лавров Н. П.] 1971: [Results of raccoon dog introductions in different parts of the Soviet Union]. - Trudy Kafedry Biologii MGZPI 29: 101-160. [In Russian]. 
Lappalainen, M. \& Vuorisalo, T. 1996: Kaikenkarvaiset kaupunkilaiset. - TS-Yhtymä, Turku.

Lindström, E. 1994: Large prey for small cubs — on crucial resources of the boreal red fox population. - Ecography 17: $17-22$

Macdonald, D. 1987: Running with the fox. - Unwin Hyman, London.

Mayr, E. 1970: Populations, species and evolution: An abridgement of animal species evolution. - Harvard University Press, Cambridge.

Meiri, S., Dayan, T. \& Simberloff, D. 2005a: Variability and sexual dimorphism in carnivores: testing the niche variation hypothesis. - Ecology 1432-1440.

Meiri, S., Dayan, T. \& Simberloff, D. 2005b: Variability and correlations in carnivore crania and dentition. - Functional Ecology 19: 337-343.

Shine, R. 1989: Ecological causes for sexual dimorphism: a review of evidence. - Quarterly Review of Biology 64: 419-461.

Slatkin, M. 1984: Ecological cause of sexual dimorphism. Evolution 38: 622-630.

Sutor, A., Kauhala, K. \& Ansorge, H. 2010: Diet of the raccoon dog - a canid with an opportunistic foraging strategy. - Acta Theriologica 55: 165-176.

Szuma, E. 2007: Geography of dental polymorphism in the red fox and its evolutionary implications. - Biological Journal of Linnean Society 90: 61-84.

Szuma, E. 2008a: Geography of sexual dimorphism in the tooth size of the red fox Vulpes vulpes (Mammalia, Carnivora). - Journal of Zoological Systematic and Evolutionary Research 46: 73-81

Szuma, E. 2008b: Evolutinary and climatic factors affecting tooth size in the red fox Vulpes vulpes in the Holarctic. - Acta Theriologica 53: 289-332.

Van Valkenburgh, B. 1989: Carnivore dental adaptations and diet: a study of trophic diversity withing guilds. - In: Gittleman, J. L. (ed.), Carnivore behaviour, ecology, and evolution vol. 1: 410-436. Chapman \& Hall, London.

Van Valkenburgh, B. 1990: Skeletal and dental predictors of body mass in carnivores. - In: Damuth, J. \& MacFadden, B. J. (eds.), Body size in mammalian paleobiology: estimation and paleobiological implications: 181-207. Cambridge University Press.

Ward, O. G. \& Wurster-Hill, D. H. 1990: Nyctereutes procyonides. - Mammalian Species 358: 1-5.

Yom-Tov, Y., Yom-Tov, S. \& Baagøe, H. 2003: Increase of the skull size in the red fox (Vulpes vulpes) and Eurasian badger (Meles meles) in Denmark during the twentieth century: an effect of improved diet? - Evolutionary Ecology Research 5: 1037-1048. 